\title{
Identification of Maize Kernel Endosperm Proteins Associated with Resistance to Aflatoxin Contamination by Aspergillus flavus
}

\author{
Z.-Y. Chen, R. L. Brown, K. E. Damann, and T. E. Cleveland
}

First and third authors: Department of Plant Pathology and Crop Physiology, Louisiana State University Agricultural Center, Baton Rouge 70803; and second and fourth authors: Southern Regional Research Center, United States Department of Agriculture-Agricultural Research Service, New Orleans 70179.

Accepted for publication 4 April 2007.

\begin{abstract}
Chen, Z.-Y., Brown, R. L., Damann, K. E., and Cleveland, T. E. 2007. Identification of maize kernel endosperm proteins associated with resistance to aflatoxin contamination by Aspergillus flavus. Phytopathology 97:1094-1103.

Aflatoxins are carcinogens produced mainly by Aspergillus flavus during infection of susceptible crops such as maize (Zea mays). Previously, embryo proteins from maize genotypes resistant or susceptible to A. flavus infection were compared using proteomics, and resistanceassociated proteins were identified. Here, we report the comparison of maize endosperm proteins from five resistant and five susceptible genotypes, and the identification of additional resistance-associated proteins

embryogenesis abundant proteins (LEA3 and LEA14), a stress-related peroxiredoxin antioxidant (PER1), heat-shock proteins (HSP17.2), a cold-regulated protein (COR), and an antifungal trypsin-inhibitor protein (TI). The gene encoding one such upregulated protein, PER1, was cloned and overexpressed in Escherichia coli. The overexpressed PER1 protein demonstrated peroxidase activity in vitro. In addition, perl expression was significantly higher in the resistant genotype Mp420 than in the susceptible genotype B73 during the late stage of kernel development, and was significantly induced upon A. flavus infection, suggesting that it may play an important role in enhancing kernel stress tolerance and aflatoxin resistance. The significance of other identified proteins to host resistance and stress tolerance also is discussed.
\end{abstract} using the same approach. Ten protein spots were upregulated twofold or higher in resistant lines compared with susceptible ones. Peptide sequencing of these proteins identified them as a globulin-2 protein, late
Additional keywords: corn, oxidative stress.
Infection of maize (Zea mays L.) kernels in the field (preharvest) and during storage (postharvest) by Aspergillus flavus Link:Fries and subsequent contamination with aflatoxins is a recurring problem in the southern United States, especially in dry and hot weather conditions (40). The dominant aflatoxin produced during the infection is aflatoxin $B_{1}$, which is the most potent carcinogenic substance produced in nature (46). Aflatoxin contamination not only reduces the value of grain as an animal feed and as an export commodity (38) but also has been linked to increased mortality in farm animals (45) and increased incidence of liver cancer in humans (28).

Currently, measures for controlling aflatoxin contamination in susceptible crops, such as maize, include cultural practices (early planting, crop rotation, irrigation, and rapid drying after harvest), biocontrols, and chemical controls (insecticide) (40). In addition, the genetic engineering approach to enhance maize plant insect resistance (such as Bt corn) has been shown to reduce aflatoxin contamination in areas where high southwestern corn borer infestations occur (58). Enhancing host plant resistance to A. flavus infection and aflatoxin contamination in maize, however, is deemed the most cost-effective control measure (3). Several maize genotypes, such as Mp420, Mp313E, MI82, and GT-MAS:gk, have demonstrated resistance to aflatoxin accumulation in both field and laboratory studies $(4,5,22,32,43,57)$. However, progress in incorporating resistant traits from these lines into genotypes with desirable agronomical traits has been slow, mainly due to the lack of markers known to be consistently associated with resistance

Corresponding author: Z.-Y. Chen; E-mail address: zchen@agcenter.lsu.edu

doi:10.1094/PHYTO-97-9-1094

(C) 2007 The American Phytopathological Society
(4). Recent genetic studies further indicated that resistance of maize kernels to aflatoxin is a multigene-controlled quantitative trait, and is under strong environmental control $(17,39)$.

Studies to understand host resistance mechanisms in maize against $A$. flavus infection and aflatoxin contamination indicate that proteins are a major factor contributing to kernel resistance $(12,15,24,29)$. The expression of a $14-\mathrm{kDa}$ trypsin-inhibitor protein (TI) was shown to be associated with resistance in vivo (12). In addition, TI demonstrated strong antifungal activity in vitro against $A$. flavus and other fungal pathogens through inhibiting the production and activity of $A$. flavus $\alpha$-amylase (11). Reduced $\alpha$-amylase production and activity can limit the available carbon source, which has been shown to reduce fungal growth and aflatoxin biosynthesis (60). Further investigation determined that both constitutive and induced proteins are required for maize kernel resistance to aflatoxin production (8).

Recently, a comparative proteomic approach was employed to identify maize kernel proteins that may serve as markers for breeders to use in marker-assisted breeding strategies. In these investigations, the expression of over a dozen constitutive kernel embryo proteins were found to be associated with resistance (either unique or fivefold upregulated in resistant lines) (9). One of the identified proteins is a stress-related protein, called glyoxalase I, which had been shown to enhance stress tolerance (54). Further examination of glyoxalase I revealed a potentially important role for it in resistance through controlling the level of its substrate, methylglyoxal, which is an aflatoxin inducer (10). In addition to glyoxalase I, other stress-related resistance-associated proteins (RAPs) identified in the comparison include a small heatshock protein (17.9 HSP), a water-stress-inducible protein (WSI 18), and an aldose reductase (9). In light of the positive relationship between drought and aflatoxin contamination in the field 
(40), the identification of these stress-related proteins may indicate a correlation between a kernel's resistance to A. flavus infection or aflatoxin production and its ability to tolerate stress (9).

Among the maize RAPs identified in the above investigations was a pathogenesis-related protein (PR-10) found in the kernel endosperm (13). Leaf extracts of transgenic tobacco plants overexpressing this PR-10 showed increased RNase activity and antifungal activity toward $A$. flavus, indicating the potential for a direct involvement in host resistance (13). However, PR-10 was the only differentially expressed endosperm protein characterized in the earlier study. Therefore, the objectives of this study were to identify other proteins differentially expressed in the endosperm tissue between resistant and susceptible maize lines, and further characterize one of such proteins, a peroxidredoxin antioxidant (PER1) protein. This protein was expressed at higher levels in resistant lines than in susceptible ones. In addition, the overexpressed PER1 demonstrated peroxidase activity in vitro, and the expression of its corresponding gene was induced in the resistant line upon fungal infection, suggesting that PER1 may play an important role in enhancing kernel stress tolerance and aflatoxin resistance.

\section{MATERIALS AND METHODS}

Chemicals and materials. Immobilized $\mathrm{pH}$ gradient (IPG) buffer ( $\mathrm{pH} 3.0$ to 10.0, linear), Immobiline DryStrip (pH 3.0 to $10.0,18 \mathrm{~cm}$ ), dithiothreitol (DTT), IPGphor, and a Hoefer-Dalt 2D electrophoresis system were purchased from Amersham Pharmacia Biotech (Piscataway, NJ). 3-([3-Cholamidopropyl]-dimethylammonio)-1-propane-sulfonate (CHAPS), ammonium persulfate, and $\mathrm{N}, \mathrm{N}, \mathrm{N}^{9}, \mathrm{~N}^{9}$-tetramethyl-ethylenediamine (TEMED) were purchased from Bio-Rad (Hercules, CA). Kernels of five aflatoxin-resistant (GT-MAS:gk, CI2, MI82, Mp420, and Mp313E) and five aflatoxin-susceptible (P3154, G4666, B73, Mo17, and Va35) maize genotypes were obtained from the same sources as described in a previous report (9). Their resistance or susceptibility to A. flavus infection or aflatoxin production has been established in earlier studies $(5,25,43)$.

Protein extraction. Kernels (20 g) from each genotype were separated into embryo and endosperm as previously described (9). Endosperm tissues were frozen in liquid nitrogen, ground, and extracted at $4^{\circ} \mathrm{C}$ as previously described (9) with an extraction buffer $(0.25 \mathrm{M} \mathrm{NaCl}, 50 \mathrm{mM}$ Tris- $\mathrm{HCl} \mathrm{pH} 8.0,14 \mathrm{mM} \beta$-mercaptoethanol, and $0.04 \%$ Pefabloc proteinase inhibitor) $(2 \mathrm{ml} / \mathrm{g})$. Protein concentration in each extract was assayed according to Bradford (2) using the Bio-Rad dye reagent and bovine serum albumin as a standard. Then, an appropriate amount of proteins from each genotype was precipitated twice with five volumes of cold acetone to remove salt (9) and dried under vacuum before resolubilizing in lysis buffer (9.5 M urea; 2\% CHAPS; $1 \%$ DTT; $0.8 \% \mathrm{wt} / \mathrm{vol}$ IPG buffer, $\mathrm{pH} 3$ to 10 ; and $0.04 \%$ Pefabloc proteinase inhibitor) at a final concentration of $2 \mu \mathrm{g} / \mu \mathrm{l}$. The resultant mixture was centrifuged for $30 \mathrm{~min}$ at $35,000 \times \mathrm{g}\left(15^{\circ} \mathrm{C}\right)$ to prepare the supernatant for loading onto a rehydrated IPG gel strip. Two protein extractions were performed for each genotype used in this study, and each protein sample was resolved in triplicate gels.

Two-dimensional gel electrophoresis. First-dimensional isoelectric focusing was performed at $20^{\circ} \mathrm{C}$ using rehydrated IPG gel strips ( $\mathrm{pH} 3$ to 10) as previously described (9). Of the above supernatant, $50 \mu \mathrm{g}$ (analytical) to $700 \mu \mathrm{g}$ (preparative) was loaded per gel strip. At the end of isoelectric focusing, gel strips were equilibrated immediately for $15 \mathrm{~min}$ in $10 \mathrm{ml}$ of sodium dodecyl sulfate (SDS) equilibration buffer $(50 \mathrm{mM}$ Tris- $\mathrm{HCl}$ buffer, $\mathrm{pH}$ 8.8; $6 \mathrm{M}$ urea; $30 \% \mathrm{wt} / \mathrm{vol}$ glycerol; $2 \% \mathrm{wt} / \mathrm{vol}$ SDS; and $1 \%$ wt/vol DTT) (23). After equilibration, IPG strips were embedded in $1 \%$ agarose solution at the top of the second-dimensional (2-D) gel. SDS-polyacrylamide gel electrophoresis (PAGE) was per- formed in $13.5 \%$ polyacrylamide gels (235 by 190 by $1.5 \mathrm{~mm}$, width by length by height) at $10^{\circ} \mathrm{C}$ at a constant voltage of $120 \mathrm{~V}$ for 2,000 Vh as described (9).

Staining and gel analysis. Protein spots in analytical or preparative gels were stained automatically with Silver Stain Kits (Genomic Solutions, Chelmsford, MA), or Coomassie Brilliant Blue R 250, respectively, in an Investigator Gel Processor (Genomic Solutions). All stained gels were scanned using a UMAX PowerLook II scanner (UMAX data systems, Taiwan), and analyzed using Progenesis Discovery 2003 software package (Nonlinear Dynamic, Durham, NC). Protein spots between replicated gels of the same extraction first were matched automatically after warping each gel to a reference gel, with some post-matching manual editing to correct mismatches. After spot matching, gels from resistant and susceptible genotypes were organized into two subgroups. Composite gels were constructed from each subgroup, and were used to compare for protein differences to homogenize genetic differences between the genotypes. The normalized volume, which had adjusted for background, loading, and staining variations between gels, was used as a criterion to compare protein expression between genotypes. The matched spots that showed significant differences in their expression between two subgroups based on least significant differences analysis then were highlighted by the software as possible candidates. Protein spots with mean expression levels from two extractions that were at least twofold higher in the resistant subgroup compared with the susceptible subgroup then were selected for peptide sequencing as described below.

Peptide sequencing and database sequence homology analysis. Protein spots were excised from the Coomassie Brilliant Blue R 250-stained 2-D gels with a combined amount of 10 to 20 pmol. These protein spots then were subjected to in-gel trypsin digestion and sequenced as previously described (9) using an electrospray ionization tandem mass spectrometry (ESI-MS/MS) equipped with a Protana nanospray source (Odense, Denmark). Peptide sequence homology searches were performed using BLAST (1) against known proteins and translated open reading frames of expressed sequence tags (ESTs) in databases at the National Center for Biotechnology Information (NCBI) and SWISS-Prot.

Cloning of the full-length 1-cys peroxiredoxin antioxidant gene (per1) from a maize endosperm cDNA library. Two degenerate primers were synthesized, 5'-GAGCT(G/C/T)GA(C/T)TCIACICA(C/T)GGIAA-3' (PER1-F0) and 5'-GGT(C/T)TC(G/A)AAICC(C/T)TGIGG(G/A)AACAT-3' (PER1-R0), based on peptide sequences ELDSTHGK and MFPQGFET, respectively. The first-round polymerase chain reaction (PCR) was performed in a 50- $\mu \mathrm{l}$ volume using a cDNA library-specific primer J19 (5'-ATCGAATTAGGATCCTCTGCT-3') and the PER1-R0 primer. The template was $1 \mu \mathrm{l}$ of an undiluted endosperm cDNA library (in pAD-GAL4-2.1 vector) made from Ohio 43 kernels that were 10 to 14 days after pollination (titer $1.1 \times 10^{9} \mathrm{pfu} / \mathrm{ml}$ ) (kindly provided to us by Dr. Robert J. Schmidt, Division of Biology, University of California, San Diego). The second-round PCR was performed using the PER1-F0 and PER1-R0 pair and $1 \mu \mathrm{l}$ of the 1:20 diluted first-round PCR product as a template. The amplified 0.6-kb PCR product was cloned into the pCR2.1TOPO vector (Invitrogen, Carlsbad, CA). DNA sequences of five independent clones were identical and aligned to the perl gene from barley. The remaining sequences of perl cDNA were cloned using $5^{\prime}$ and $3^{\prime}$ rapid amplification of cDNA ends (RACE) with primers from the cDNA library vector (J19 and J20: 5'-CTCGAGATGCTAGCGAGTATCCTTTTTTTT-3') and gene-specific primers (PER1-F1: 5'-GACGACGAAGGTGACGTT-3' and PER1-F2: 5'-TCCGGCAGCTGAACATGGT-3' for cloning the 3' end; PER1-R1: 5'-TCAGCTTGACGGCCTTGTC-3' and PER1R2: 5'-ATCGGGAACGTCACCTTCG-3' for cloning the 5' end) derived from the sequenced $0.6-\mathrm{kb}$ PCR product. The resulting PCR products then were cloned as above and sequenced using a 
dye termination reaction on an ABI 377 DNA sequencer (Applied Biosystems Inc., Warnngton, UK).

Overexpression of PER1 in Escherichia coli. The coding region of perl cDNA was amplified using two primers (PER1NcoI: 5'-AACCATGgCGGGGCTCAC-3' and PER1-SacI: 5'AGAgcTCCGTGCCGTACGTC-3'). The nucleotide substitutions (lowercase) to incorporate a $\mathrm{NcoI}$ site at the $5^{\prime}$ end (by changing $\mathrm{C}$ to $\mathrm{G}$ ) and a SacI site at the $3^{\prime}$ end (by changing CA to GC) changed only the second amino acid residue from $\mathrm{P}$ to $\mathrm{A}$ at the $\mathrm{N}$ terminus of the maize PER1. The PCR product was digested with NcoI and SacI, gel purified, and cloned into the corresponding sites of the pET28c vector (Novagen, Madison, WI) to generate the pET28c-PER1. Correct construct was verified through DNA sequencing.

The construct then was transformed into an E. coli expression host BL21 (DE3). The molecular mass of the overexpressed maize PER1 was predicted to be $24.9 \mathrm{kDa}$, containing only the complete mature PER1 sequence (229 amino acid residues). The induction of PER1 expression and the fractionation were performed according to Chen et al. (11). Each fraction then was resolved using SDS-PAGE according to Laemmli (33). The content of overexpressed PER1 in the total cell extract and in the soluble fraction was quantified with a Bio-Rad GS-700 gel densitometer.

Gel staining of peroxidase activity. Various fractions of E. coli protein extracts first were resolved using native polyacrylamide gels (13.5\%), and then the peroxidase activity was visualized according to Shimoni et al. (44). Gels first were incubated in $150 \mathrm{ml}$ of sodium acetate buffer solution $(0.05 \mathrm{M}$, pH 5.0) containing $10 \mathrm{mM} \mathrm{H}_{2} \mathrm{O}_{2}$. After 1 to $2 \mathrm{~min}, 3 \mathrm{ml}$ of $\mathrm{N}, \mathrm{N}-$ dimethylformamide containing $30 \mathrm{mg}$ of 3-amino-9-ethylcarbazol was added with slow shaking. Brown bands were visible in 5 to $10 \mathrm{~min}$.

Expression of per1 during maize kernel development with and without A. flavus inoculation. The effect of fungal colonization on perl expression during maize kernel development was studied in a resistant (Mp420) and a susceptible (B73) maize genotype in spring 2004. Seven days after pollination, one-third $(\approx 100)$ of the plants from each genotype were inoculated in the field with $5 \mathrm{ml}$ of $A$. flavus suspension $\left(5 \times 10^{6}\right.$ conidia/ml $)$ per ear at multiple locations in the mid-ear using a syringe. Another one-third of the plants were wounded with a syringe needle without inoculum to serve as a wounded-only control. The remaining one-third of the plants were used as a noninfected (nonwounded) control. Six wounded-only or inoculated ears were harvested at the following time intervals: $0,1,2,3,5,8,12,16$, and 24 days after inoculation (DAI) and divided into three replicates, each with two ears. Six noninfected control ears also were harvested on the same days. Kernels harvested from two randomly selected ears of the same genotype and treatment were combined as one replicate and frozen in liquid nitrogen before storing at $-80^{\circ} \mathrm{C}$.
For inoculated and wounded ears, only healthy-looking, intact kernels surrounding the inoculation or wounding sites were collected. Ears were harvested at a fixed time during the day to avoid any circadian effect on gene expression. For each sampling date, kernels were removed from the cob as soon as ears were harvested. This experiment was repeated in a different field in the same growing season.

Total RNA was isolated from immature maize kernels of different developmental stages using the RNeasy Plant mini kit (Qiagen, Valencia, CA) and reverse transcribed into cDNA as previously described (13) according to the manufacturer's instructions. The level of perl expression then was quantified using an ABI 5700 Thermal Cycler with SYBR Green dye chemistry (Applied Biosystems). Primers used in real-time reverse-transcriptase PCR (PER1-F, 5'-CAAGATCCGCATCCACGACTA-3' and PER1-R, 5'-TCGGCTGGGTGGGAGAA-3') were designed using Primer Express 2.0 (Applied Biosystems). The amplicon size was $90 \mathrm{bp}$. Dissociation kinetics was performed by the machine at the end of the experiment to examine the annealing specificity of primers. In addition, the amplified product was sequenced to confirm the specific amplification. The expression of 18S rRNA in maize kernels was used as an internal control to normalize the expression of the perl gene (13). Using standardized conditions, deviations of threshold values usually were $<1.0$ cycle for independent cDNA preparations from replicated samples of the same time point and treatment, and $<0.5$ cycle for replicates of the same cDNA. The replication variation of data between the repeated experiments was determined by comparing the means using least significant difference and was not statistically different $(P=0.05)$. Therefore, the data were combined and reported here.

Statistical analysis. All statistical analyses were conducted using the SAS software package (version 8.2; SAS Institute, Cary, NC). Means for protein expression were separated using a least significant difference test at $P=0.05$. Mean separations for perl expression in maize kernels during different developmental stages were performed using the method of Duncan's multiple range test $(P=0.05)$.

\section{RESULTS}

Identification of differentially expressed endosperm proteins. Endosperm proteins first were detected, quantified, and matched for each gel using Progenesis Software. The number of protein spots detected in the endosperm was usually between 800 and 1,200 when stained with silver, less than that observed in the embryo. Of the matched proteins, 109 spots were identified as present in all resistant genotypes and 114 spots were present in all susceptible genotypes. Of the 109 spots present in all resistant genotypes, 42 were missing in one or more susceptible genotypes, and 47 of those present in all susceptible genotypes were missing in one or more of the resistant genotypes. However, none of these

TABLE 1. Summary of twofold or more upregulated protein spots identified in endosperm of five aflatoxin-resistant maize genotypes compared with five susceptible genotypes

\begin{tabular}{|c|c|c|c|c|}
\hline Spot number & Normalized volume in $\mathrm{R}^{\mathrm{a}}$ & Isoelectric point ${ }^{b}$ & Molecular weight ${ }^{\mathrm{b}}$ & Fold of upregulation \\
\hline 529 & $0.625 \pm 0.091$ & $9.56 \pm 0.01$ & $24,740.8 \pm 248.3$ & 2.16 \\
\hline 533 & $0.282 \pm 0.063$ & $5.27 \pm 0.02$ & $27,518.0 \pm 1,227.6$ & 2.74 \\
\hline 537 & $0.116 \pm 0.039$ & $6.21 \pm 0.03$ & $27,304.4 \pm 1,327.5$ & 2.08 \\
\hline 546 & $0.180 \pm 0.071$ & $6.80 \pm 0.04$ & $26,785.0 \pm 1,194.2$ & 2.17 \\
\hline 646 & $0.216 \pm 0.106$ & $5.44 \pm 0.03$ & $20,101.9 \pm 429.1$ & 2.31 \\
\hline 678 & $0.280 \pm 0.133$ & $5.48 \pm 0.02$ & $19,084.5 \pm 659.1$ & 2.52 \\
\hline 717 & $0.176 \pm 0.083$ & $5.19 \pm 0.03$ & $14,934.4 \pm 474.5$ & 3.10 \\
\hline 798 & $1.977 \pm 0.708$ & $6.07 \pm 0.05$ & $11,682.7 \pm 226.1$ & 2.09 \\
\hline $852^{c}$ & $0.166 \pm 0.089$ & $6.03 \pm 0.03$ & $9,124.7 \pm 564.5$ & 2.04 \\
\hline 1433 & $0.127 \pm 0.014$ & $6.20 \pm 0.02$ & $11,320.5 \pm 341.3$ & 2.45 \\
\hline
\end{tabular}

a Normalized volume: the values presented here are means \pm standard error in all resistant genotypes.

b The values for isoelectric point and molecular weight are the means of the same spot obtained from replicated gels in two experiments.

c The spot was not visible in prep gel. 
spots were completely missing in the other group. The remaining 67 spots were present in all genotypes. Of these, 10 were expressed at a level twofold or higher in resistant genotypes than in susceptible genotypes (Table 1), and 6 of them were downregulated between four- to twofold in the resistant genotypes compared with susceptible ones. The protein that showed the highest upregulation (3.1-fold) in resistant lines was PR-10. Examples of one upregulated protein spot (533) and one downregulated protein spot (1022) are shown in Figures 1 and 2, respectively.

Peptide sequencing and homology analysis of resistanceassociated proteins. After gel analysis, the upregulated protein spots in resistant lines were recovered, digested, and sequenced using ESI-MS/MS. Two to four peptides were sequenced from each spot for positive protein identification. The peptide sequences obtained from each spot and their homology identified through database searches are summarized in Table 2. Spot 529 is identified as a maize group 3 late embryogenesis abundant protein (LEA3) based on its peptide sequence homology. The peptide sequence of spot 533 is highly homologous (98.2\% identity) to a maize globulin 2 protein (GLB2). However, the molecular mass of spot 533 is only $25.6 \mathrm{kDa}$ based on gel estimation, and the peptide sequence is aligned to the middle region of GLB2. This suggests that spot 533 is derived from GLB2 through a partial proteolytic processing.

For spots 537 and 546, four and three peptide sequences were obtained, respectively; and two of them were identical between the two spots (Table 2). All of these sequenced peptides showed high homology (94.8 to $82.8 \%$ identity) to a peroxiredoxin
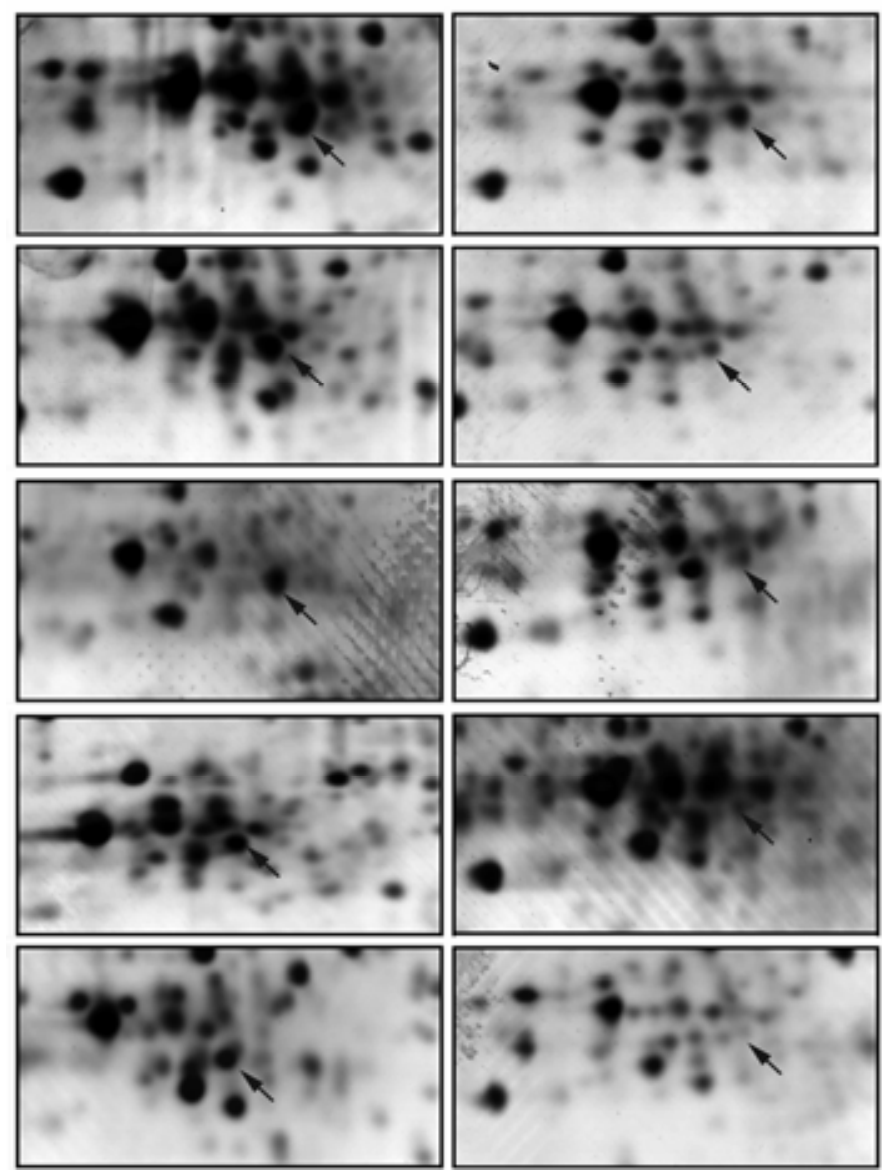

Fig. 1. Subsections of representative two-dimensional gels showing an upregulated endosperm protein spot 533 (indicated with filled arrows) in the proteomic comparison between five aflatoxin-resistant and five susceptible maize genotypes. The gel images on the left side are from resistant maize genotypes GT-MAS:gk, CI2, Mp313E, MI82, and Mp420 (from top to bottom) and the gels on the right side are from susceptible genotypes G4666, Mo17, P3154, B73, and Va35 (from top to bottom). antioxidant protein from barley (X96551), a 1-cys peroxiredoxin protein (PER1) from wheat (AF327046), and an ABA-responsive 24-kDa protein with probable peroxiredoxin (thioredoxin peroxidase) activity from rice (RAB24, P52573). PER1 is a subgroup of the most recently discovered types of enzymatic antioxidants with one conserved cysteine residue at the $\mathrm{N}$ terminus and possessing peroxidase activities. The two protein spots have similar molecular masses, but different isoelectric points (pIs), suggesting that the two proteins are encoded by two highly homologous genes or by one gene with different post-translational modifications.

Three peptide sequences were obtained for spot 646 (Table 2). They are highly homologous to cold-regulated proteins from wheat (cor18, accession no. AB097412), barley (accession no. AJ291295, 81.8\% identity), and the deduced amino acid sequences of ESTs from maize (CO456082) and rice (XM_475410). The deduced amino acid sequences of the maize EST showed the highest sequence similarity $(93.2 \%$ identity) to the sequenced peptides. Peptide sequences of spot 678 (Table 2) showed high homology to a group 4 LEA (LEA14) from cotton (accession no. P46518, 60.9\% identity), a desiccation-related protein from Arabidopsis thaliana (accession no AAC62908, 56.5\% identity), a desiccation protectant protein from soybean (accession no. P46519, 56.5\% identity), and a putative LEA from rice (accession no. BAB19059, 86.9\% identity) (Fig. 3). These peptides also are highly homologous to the deduced amino acid sequences of several maize ESTs, such as AW331170 (73.9\%) and AW566229 (78.3\%) (Fig. 3). These data suggest the presence of multiple genes encoding group 4 LEA proteins in maize.
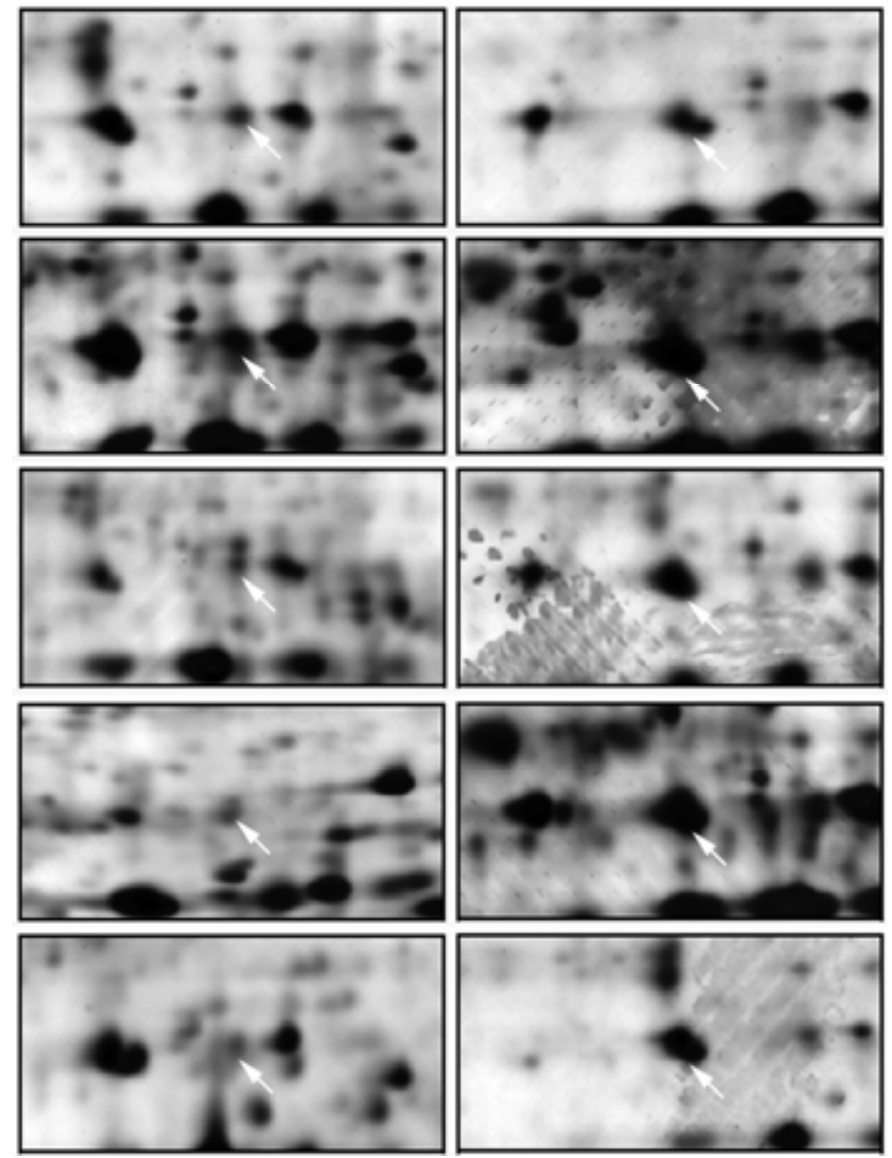

Fig. 2. Subsections of representative two-dimensional gels showing a twofold downregulated endosperm protein spot 1022 (indicated with open arrows) in the proteomic comparison between five aflatoxin-resistant and five susceptible maize genotypes. The gel images on the left side are from resistant maize genotypes GT-MAS:gk, CI2, Mp313E, MI82, and Mp420 (from top to bottom) and the gels on the right side are from susceptible genotypes G4666, Mo17, P3154, B73, and Va35 (from top to bottom). 
Based on the obtained peptide sequences, both spots 798 and 1433 are identified as the maize $14-\mathrm{kDa}$ TI (Fig. 4). The peptide sequences also showed high sequence identity to TIs from barley (55.2\%) and finger millet (62.1\%) (Fig. 4). The mismatch (L/M) between one peptide sequence from spot 1433 and the maize 14$\mathrm{kDa}$ TI1 (CCA37998) at amino acid residue position 68 appears to be real because it completely matched to another maize $14-\mathrm{kDa}$
TI2 (ABA34134) (Fig. 4). This indicates that the two discrete TI spots identified on 2-D gels may have arisen from two homologous genes rather than from a single gene with different posttranslational modifications.

The peptides of spot 1113 are highly homologous $(88.1 \%$ identity) to small HSPs from maize (accession no. S23212), pearl millet (S72545), and rice (P27777) (Fig. 5). Three of the peptide

TABLE 2. Summary of peptide sequences obtained from 10 protein spots that were upregulated in the endosperm of aflatoxin-resistant maize genotypes through electrospray ionization tandem mass spectrometry

\begin{tabular}{|c|c|c|c|c|c|}
\hline Spot no. & Peptide sequences ${ }^{\mathrm{a}}$ & Accession $^{\mathrm{b}}$ & Identity or homology & E value $^{\mathrm{c}}$ & References \\
\hline 529 & $\begin{array}{l}\text { ASDTGSYLGK } \\
\text { DAVMSTLGMGGDDK }\end{array}$ & $\begin{array}{l}\text { Z29512, } \\
\text { U05226 }\end{array}$ & LEA3 from maize & $4 \mathrm{e}-05$ & 6,56 \\
\hline 533 & $\begin{array}{l}\text { EGEGVIVLLSGGK } \\
\text { GAVVYSANTHQSEWFR } \\
\text { VVMLLSPVVSTSGR } \\
\text { GEITTASEEQIR }\end{array}$ & X53715 & Globulin 2 from maize & $8 \mathrm{e}-09$ & 50,55 \\
\hline 537 & $\begin{array}{l}\text { VTFPI(L/I)ADPAR } \\
\text { LSFLYPATTGR } \\
\text { AVDSLLTAAK } \\
\text { MFPQGFETADLPSK }\end{array}$ & X96551 & 1-Cys peroxiredoxin antioxidant (PER1) from barley & $8 \mathrm{e}-04$ & 37,47 \\
\hline 546 & $\begin{array}{l}\text { VPNLELDSTHGK } \\
\text { VTFPI(I/L)ADPAR } \\
\text { MFPQGFETADLPSK }\end{array}$ & P52572 & 1-Cys peroxiredoxin antioxidant (PER1) from barley & 0.11 & 37,47 \\
\hline 646 & $\begin{array}{l}\text { SPPLEWYGVPGGAAR } \\
\text { GLPEGFSGAAGAGAGAGR } \\
\text { LGGLQEGVNDWK }\end{array}$ & $\begin{array}{l}\text { AB097412, } \\
\text { AJ291295 }\end{array}$ & Close to cold-related protein from wheat & 0.011 & 16 \\
\hline 798 & $\begin{array}{l}\text { ELADIPAYCR } \\
\text { SILMDGAIPPGPDAQLEGR }\end{array}$ & $\begin{array}{l}\text { DQ898140, } \\
\text { X54064 }\end{array}$ & Bifunctional trypsin or amylase inhibitor & $6 e-07$ & 12 \\
\hline 1113 & $\begin{array}{l}\text { TSSETAAFAGAR, ETPEAHVFK } \\
\text { VEVEDGNVLQISGER, RFRLPENAK }\end{array}$ & X94193 & Close to heat-shock protein 17.9 from pearl millet & 0.073 & 53 \\
\hline 1433 & $\begin{array}{l}\text { LPWPEMK } \\
\text { ELADIPAYCR } \\
\text { PPGPDAQLEGR }\end{array}$ & $\begin{array}{l}\text { DQ147267, } \\
\text { DQ898140, } \\
\text { X54064 }\end{array}$ & Bifunctional trypsin/ amylase inhibitor from maize & 0.010 & 12 \\
\hline
\end{tabular}

a The amino acid $\mathrm{L}$ and I shown in parentheses in the peptide sequences cannot be distinguished by mass spectrometry.

${ }^{b}$ The accession numbers of sequences that show highest homology to the query peptide sequences in the BLAST search.

${ }^{c}$ Expected (E) value is a parameter that describes the number of expected hits by chance when searching a database of a particular size. It takes into account the length of the query sequence. A relatively high $\mathrm{E}$ value is possible even though a significant homology exists between the query and the database sequence when a short query sequence is used for database search, as in this study, due to the fact that shorter sequences have a high probability of occurring in the database purely by chance.

BAB19059
SPOT 678
AW331170
SPOT 1868
AW56 6229
LEA14-GH
LEA14-GM
AAC62908

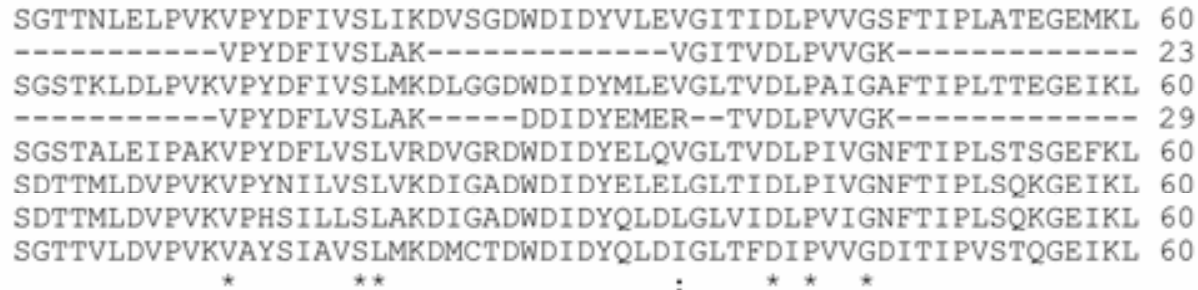

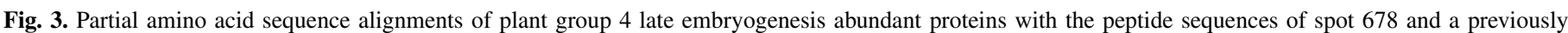

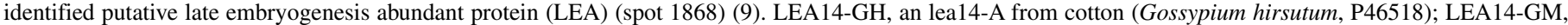

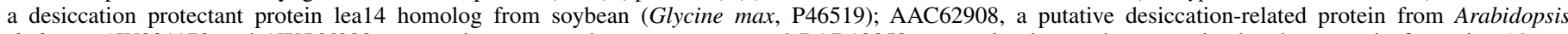

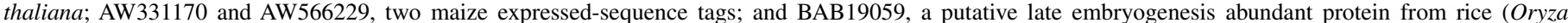
sativa). The conserved amino acid residues are indicated with "*” and the one amino acid mismatch between spots 678 and 1868 is indicated with ":".

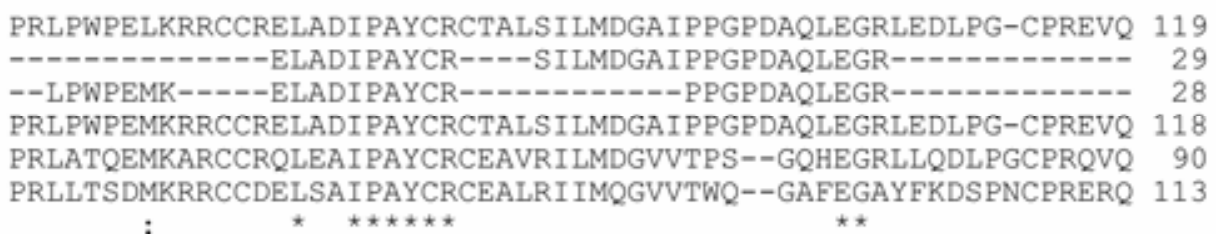

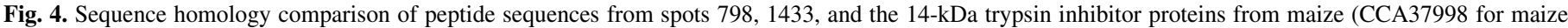

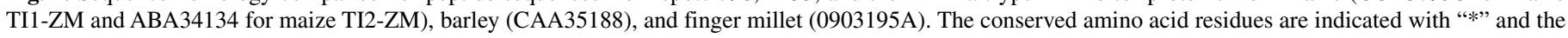
one amino acid mismatch between TI1-ZM and spot 1433 is indicated with “:”. 
sequences also were identical to a previously sequenced putative embryo HSP (spot 1724) (9). The peptide sequences also completely match the deduced amino acid sequences of two maize ESTs (BE123268 and AW258080) and are highly homologous (97.5 to $92.9 \%$ identity) to that of three other ESTs (BE056217, AW067565, and BE639130).

Cloning of full-length cDNA encoding 1-cys peroxiredoxin antioxidant protein. To further investigate the role of RAPs identified through proteomics in host resistance, the PER1 protein was selected for further characterization. The perl gene was cloned as described in Materials and Methods. The full-length cDNA (1,037 bp), under accession no. DQ378060 in GenBank, has an open reading frame for 229 amino acids with a putative poly A site (CTAGTATATA) located at nucleotide position 861 (Fig. 6). This putative maize PER 1 protein has a calculated molecular mass and $\mathrm{pI}$ of $24,912 \mathrm{Da}$ and 6.71, respectively. BLAST search of the cDNA sequence found several maize ESTs (AW258068, AW261289, and AW255107) with identical DNA sequence to the cloned perl cDNA except at the very $5^{\prime}$ end. These ESTs, along with the cloned perl cDNA, appear to have several single-nucleotide polymorphisms compared with other maize perl homologous ETSs, such as CF000383, CO459331, CO455640, and CD443434 (data not shown).

The deduced amino acid sequence of perl shares high homology to 1-cys peroxiredoxin antioxidant from other plants, such as barley (X96551, 82\%), wheat (AF327064, 81\%), and rice (AY336994, 76\%) (Fig. 7), and contains a conserved active site (PVCTTE) at the N-terminus (Fig. 7). The perl deduced amino acid sequence was 98 and $94.8 \%$ identical to the deduced amino acid sequences of a maize clone contig519 mRNA sequence (BT016686) (Fig. 7) and a maize EST (AW225107) (data not shown), respectively. The deduced amino acid sequence also possesses a conserved domain, similar to those observed in the alkyl hydroperoxide reductase (AhpC) family, which contains proteins related to alkyl hydroperoxide reductase; and the thiol specific antioxidant (TSA) family, which contains peroxiredoxin proteins involved in posttranslational modification, protein turnover, and chaperones (35).

Peroxidase activity of maize PER1 overexpressed in $E$. coli. The maize PER 1 was successfully overexpressed in $E$. coli cells and consisted of $\approx 6 \%$ of total proteins of $E$. coli cells when induced by IPTG (Fig. 8A). The apparent molecular mass of the overexpressed protein was $\approx 25.0 \mathrm{kDa}$ based on SDS-PAGE, which was close to the predicted value of $24.9 \mathrm{kDa}$. The majority of the overexpressed protein remained in the water- or salt-soluble fraction, and some was present in the urea-soluble fraction (data not shown). The peroxidase activity (brown band) was detected in the water- or salt-soluble protein fraction of the induced E. coli cells, but not from that of the noninduced control cells when the proteins were resolved using native PAGE gels (Fig. 8B). The areas corresponding to the peroxidase activity from an unstained duplicated native gel were recovered from both the control and induced cells. The proteins recovered from the excised gels were resolved on a new SDS-PAGE. It was found that the major difference in protein profiles between the proteins recovered from the native gel of induced cell extract and those from noninduced control cell extract was the presence of the $25-\mathrm{kDa}$ protein in the induced cell extract (Fig. 8C). This protein was missing in the noninduced cell extracts, indicating that the observed peroxidase activity in the native gel was contributed by the overexpressed PER1 protein.

Expression of per1 during kernel development with or without fungal infection. Under normal kernel developmental conditions without fungal inoculation, perl expression was very low in the early stage (up to 3 DAI) in both resistant and susceptible genotypes (Fig. 9). It increased slightly between 3 to $8 \mathrm{DAI}$ and rapidly thereafter to $\approx 5$ to 10 -fold the level of $8 \mathrm{DAI}$ at 24 DAI (Fig. 9), coinciding with kernel maturation and dehydration. The transcript level in the resistant genotype Mp420 under either inoculated or noninoculated conditions was sevenfold higher than that in the susceptible B73 during the late stage

HSP16.9-PG
HSP16.9-OS
AW067565
BE639130
HSP17.2-ZM
AW258080
SPOT 1113
BE056217

HSP16.9-PG

HSP16.9-OS

AW0 67565

BE639130

HSP17.2-ZM

AW2 58080

SPOT 1113

BE0 56217

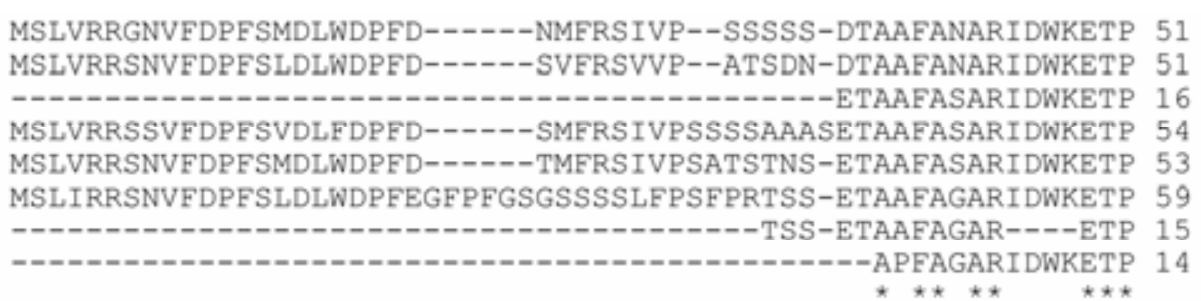

EVHVFKADLPGVKKEEVKVEVEDGNVLVISGQRSK-EKEDKNDRWHRVERSSGQ-FVRRF 109 ESHVFKADLPGVKKEEVKVEVEEGNVLVISGQRSK-EKEDKNDKWHRVERSSGQ-FMRRF 109 EAHVFKADLPGVKKEEVKVEVEDGNVLLISGQRSR-EKEDKGDKWHRVERSSGQ-FVRRF 74 EAHVFKADLPGVKKEEVKVEVEDGNVLLISGQRSRXRRRTXGDKWHRVERSSGQ-FVRRF 113 EAHVFKADLPGVKKEEVKVEVEDGNVLVISGQRSR-EKEDKDDKWHRVERSSGQ-FIRRF 111 EAHVFKADVPGLKKEEVKVEVEDGNVLQISGERNK-EQEEKTDTWHRVERSSGR-FLRRF 117

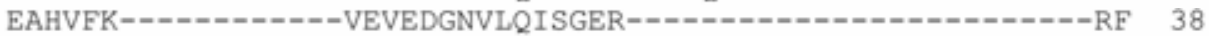
EAHVFKADVPGLKKEEVKVEVEDGNVLQISGERNK-EQEEKTDTWHRVERSSGR-FLRRF 72

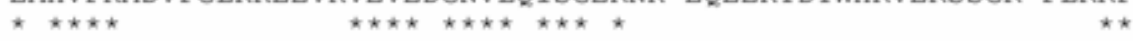
$\begin{array}{lr}\text { RLPEDAKTDQVNAGLENGVLTVTVPKAEGKKPEVKAIEISG } & 150 \\ \text { RLPENAKVDQVKAGLENGVLTVTVPKAEVKKPEVKAIEISG } & 150 \\ \text { RLPENAKTEEVRAALENGVLTVTVPKAEVKKPEVKSIQISG } & 115 \\ \text { RLPENAKTEEVRAALENGVLTVTVPKAEVKKPEVKSIQIS- } & 153 \\ \text { RLPDDAKVDQVKAGLENGVLTVTVPKAEEKKPEVKAIEISG } & 152 \\ \text { RLPENAKTEQIRAAMENGVLTVTVPKEDVKKPEVK------ } & 152 \\ \text { RLPENAK-------------------------- } & 45 \\ \text { RLPENAKTEQITAAMENGVLTVTVPKEDAKKPEVKSIQISG } & 113 \\ \star \star \star \star \star \star & \end{array}$

Fig. 5. Alignment of amino acid sequences of spot 1113 with low molecular weight heat-shock proteins (HSPs) from Pennisetum glaucum (HSP16.9-PG, S72545), Oryza sativa (HSP16.9-OS, P27777), Zea mays (HSP17.2-ZM, S23212), and the deduced amino acid sequences of several maize expressed sequence tags (AW258080, AW067565, BE056217, and BE639130). The conserved amino acid residues are indicated with “*”. 
of kernel development. Upon fungal inoculation, a threefold induction of perl expression was observed in both resistant and susceptible kernels between 8 and 16 DAI (Fig. 9). However, the transcript level was still fivefold higher in Mp420 than in B73 at 24 DAI. The perl expression in the wounded-only control samples collected between 1 and 5 DAI did not show a clear induction by wounding, and the level was not significantly different from the corresponding nonwounded controls (Fig. 9). Therefore, the remaining wounded-only control samples collected at a later time were not examined.

\section{DISCUSSION}

Comparisons of kernel proteins between resistant and susceptible maize genotypes through proteomics have identified that the expression of three categories of proteins was higher in resistant than in susceptible lines and, therefore, associated with aflatoxin resistance (RAPs). These are storage proteins, stress-related proteins, and antifungal proteins. In a previous report comparing embryo proteins, two globulins (GLBs) and a couple of LEAs were identified as RAPs (9). The identification of a third GLB2 (spot 533) and another LEA3 (spot 529) in the endosperm as a RAP further suggests a potential importance of storage proteins in kernel resistance. The similar molecular masses but different pIs among the three GLB2 proteins suggest that these proteins may arise from different posttranslational modifications (50). The accumulation of LEA3 proteins was shown to occur late in embryogenesis to enhance stress tolerance (61), coinciding with the onset of dehydration (52) and the outbreak of aflatoxin production in infected kernels (40).

The expression of two antifungal proteins has been described as associated with resistance in the maize endosperm. One is a PR10 shown to be an RNase and antifungal (13). The other is the $14-\mathrm{kDa}$ TI, which also is a potent antifungal protein (12). Two of the RAPs sequenced in the present study also are TIs, supporting the potential importance of TI to host resistance.

The stress-related RAPs identified in the endosperm include small HSPs, a cold-regulated protein, and a peroxiredoxin anti-
1

61

1

121

18

181

38

241

58

301

78

361

98

421

118

481

138

541

158

601

178

661

198

721

218

781

841

901

961

1021

GAATTCTTCCGATGAGGGTAATGCGTAACCATAGCCAGCAAGCCAGCGCACGTCGGTAGG

CACGCCACCATGCCGGGGCTCACCATCGGCGACACCGTCCCCAACCTGGAGCTGGACTCC $\begin{array}{lllllllllllllllll}M & P & G & L & T & I & G & D & T & V & P & N & L & E & L & D & S\end{array}$

ACCCACGGCAAGATCCGCATCCACGACTACGTCGGCGACGGCTACGCCATCATCTTCTCC

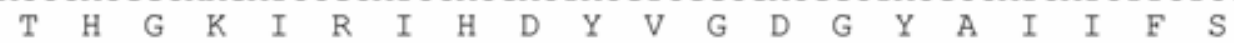

CACCCAGCCGACTTCACGCCCGTGTGCACAACGGAGATGGCGGCGATGGCGGGGTACGCC $\begin{array}{llllllllllllllllllll}\mathrm{H} & \mathrm{P} & \mathrm{A} & \mathrm{D} & \mathrm{F} & \mathrm{T} & \mathrm{P} & \mathrm{V} & \mathrm{C} & \mathrm{T} & \mathrm{T} & \mathrm{E} & \mathrm{M} & \mathrm{A} & \mathrm{A} & \mathrm{M} & \mathrm{A} & \mathrm{G} & \mathrm{Y} & \mathrm{A}\end{array}$

AAGGAGTTCGAGAAGCGTGGCGTGAAGCTGCTGGGCATCTCGTGCGACGACGTGGAGTCG $\begin{array}{llllllllllllllllllll}K & E & F & E & K & R & G & V & K & \text { L } & \text { L } & G & I & S & C & D & D & V & E & S\end{array}$

CACAGGCAGTGGACCAAGGACGTGGAGGCGTACGGCGGGAAGCAGCAGCAGCAGCAGGCG $\begin{array}{llllllllllllllllllll}H & R & Q & W & T & K & D & V & E & A & Y & G & G & K & Q & Q & Q & Q & Q & A\end{array}$

ACGACGACGAAGGTGACGTTCCCGATCCTGGCGGACCCGGCGCGGGACGCCATCCGGCAG $\begin{array}{llllllllllllllllllll}T & T & T & K & V & T & F & P & I & L & A & D & P & A & R & D & A & I & R & Q\end{array}$

CTGAACATGGTGGACCCCGACGAGAAGGACGCGGCGGGGCGGAGCATGCCGTCCCGCGCG $\begin{array}{llllllllllllllllllll}\text { L } & N & M & V & D & \text { P } & \text { D } & \text { E } & \text { K } & \text { D } & \text { A } & \text { A } & \text { G } & \text { R } & \text { S } & \text { M } & \text { P } & \text { S } & \text { R } & \text { A }\end{array}$

CTCCACGTCGTCGGGCCCGACAAGGCCGTCAAGCTGAGCTTCCTGTACCCGGCCACCACG $\begin{array}{llllllllllllllllllll}\mathrm{L} & \mathrm{H} & \mathrm{V} & \mathrm{V} & \mathrm{G} & \mathrm{P} & \mathrm{D} & \mathrm{K} & \mathrm{A} & \mathrm{V} & \mathrm{K} & \mathrm{L} & \mathrm{S} & \mathrm{F} & \mathrm{L} & \mathrm{Y} & \mathrm{P} & \mathrm{A} & \mathrm{T} & \mathrm{T}\end{array}$ GGGCGGAACATGGACGAGGTGCTGCGCGCTGTCGACTCGCTGCTCACCGCCGCCAAGCAT $\begin{array}{llllllllllllllllllll}G & R & N & M & D & E & V & L & R & A & V & D & S & L & L & T & A & A & K & H\end{array}$ GGCGGGAAGGTGGCCACGCCCGCCAACTGGAAGCCCGGGGAGTGCGCCGTCATCGCGCCC $\begin{array}{llllllllllllllllllll}G & G & K & V & A & \text { T } & \text { P } & \text { A } & \text { N } & \text { W } & \text { K } & \text { P } & \text { G } & \text { E } & \text { C } & \text { A } & \text { V } & \text { I } & \text { A } & \text { P }\end{array}$ GGCGTCTCCGACGAGGAGGCCAGGAAGATGTTCCCGCAGGGGTTCGAGACCGCCGACCTG $\begin{array}{llllllllllllllllllll}G & V & S & D & E & E & A & R & K & M & F & P & Q & G & F & E & T & A & D & L\end{array}$ CCCTCCAAGAAGGGCTACCTCCGTTTCACCAAGGTTTAGCTAGCCGACGCACGGCACGGA $\begin{array}{lllllllllllll}P & S & K & K & G & Y & \text { L } & \text { R } & \text { F } & \text { T } & \text { K } & \text { V }\end{array}$

CATCTAGCTCGTCTGTCAGTCCGCGTCGACCGGGGTGCGCGGATCTTTTGTGCCTGCTGG
TGGTTCTCTGACTAGTACTAGTATATATATAGGCTCTATGTATGTGCGTACTATGCCGT
GCCGTGTTGTCTCGTGTAGTGGTGGCAACCGGTTCGTGGCACTACCGCGCTAGTATTGTC
CACCCATATCAATGTCCTCTTCTGAACTTAGCGGCGCACATGTTTGTGCGTGTGTGTAGC
ATCTGCTAAAAAAA

Fig. 6. Cloning of the full-length perl cDNA encoding a maize peroxiredoxin antioxidant protein and the deduced amino acid sequence. The putative poly A site is shown in bold. 
oxidant protein. Their high level of expression in the resistant maize genotypes supports a connection between a kernel's resistance to A. flavus infection or aflatoxin production and its stress tolerance. High temperature and drought, which often occur together in nature, are two major factors associated with increased aflatoxin contamination of maize kernels in the field (40). Reducing drought stress through irrigation has been shown to reduce aflatoxin contamination under field conditions $(30,41)$. Possession of unique or high levels of the hydrophilic storage proteins (which are a major part of kernel dry mass) or stress-related proteins inside maize kernels, such as those identified in the present study, may put resistant lines in an advantageous position over susceptible genotypes in the ability to maintain biological activities and to defend against pathogens, especially while under stress.

A high-level expression of stress-related proteins may not only confer stress tolerance but also enhance disease resistance. The role of a glyoxalase I protein from Brassica juncea in enhancing tolerance to salt, water, and heavy metal stresses was demonstrated in an earlier study (54). The expression of this protein was found to associate with resistance in maize against aflatoxin accumulation (10). Further investigations suggest an important role for glyoxalase I in aflatoxin resistance through the removal of its aflatoxin-inducing substrate, methylglyoxal (10). Sugar beet overexpressing a stress-related superoxide dismutase from tomato exhibited increased tolerance to oxidative stress as well as to leaf infection by Cercospora beticola (51). Overexpression of another stress-related protein, peroxiredoxin Q, from Gentiana triflora in transgenic tobacco plants improved not only host stress tolerance but also disease resistance against Alternaria alternata and Botrytis cinerea (31).

To continue investigating the roles of stress-related RAPs in host resistance, the maize 1-cys peroxiredoxin antioxidant protein (PER1) identified in the present study was further characterized. Peroxiredoxins are one of the most recently discovered types of enzymatic antioxidants with peroxidase activities on substrates such as hydroperoxides and alkyl hydroperoxides $(6,19,37)$. It has been speculated that the function of peroxiredoxins is to protect plants from oxidative damages to nucleic acids, lipids, and proteins caused by rapid production of reactive oxygen species during stress or fungal infection $(27,34,59)$. Other studies also suggest a role for peroxiredoxins in pathogen defense. Peroxiredoxins were upregulated in the highly resistant $B$. carinata compared with the highly susceptible $B$. napus (canola) when challenged by the fungal pathogen Leptosphaeria maculans (49). The expression of a peroxiredoxin Q from poplar exhibited differential responses during compatible and incompatible interactions with two races of Melampsora larici-populina, the causal agent of the poplar rust (42).

The maize PER1 identified in the present study represents a subgroup of the peroxiredoxin family of thiol-requiring antioxidants with one conserved cysteine residue $(1$-cys) $(18,48)$. The high expression at protein level in the resistant maize genotypes, the constant higher transcript level of perl during kernel development in the resistant line, the induction of perl expression after inoculation, and its demonstrated peroxidase activity indicate a possible role for PER1 in host defense in response to Aspergillus flavus infection. Rapid production of reactive oxygen

\begin{abstract}
AF 327046
X96551

P52573

AY336994

ZmPER1

BT016686

MPGLTIGDTVPNLELDSTHGKIRI HDYVGNGYVI LFSHPGDFTPVCTTELAAMANYAKEF 60 MPGLTIGDTVPNLELDSTHGKIRIHDYVGNGYVILFSHPGDFTPVCTTELAAMANYAKEF 60 MPGLTIGDTVPNLELDSTHGKIRIHDFVGDTYVILFSHPGDFTPVCTTELAAMAAYAKEF 60 MPGLTIGDTVPNLELDSTHGKIRIHDFVGDTYVILFSHPGDFTPVCTTELAAMAGYAKEF 60 MPGLTI GDTVPNLELDSTHGKIRI HDYVGDGYAI I FSHPADFT PVCTTEMAAMAGYAKEF 60 MPGLTIGDTVPNLELDSTHGKIRIHDYVGDGYAI IFSHPADFTPVCTTEMAAMAGYAKEF 60

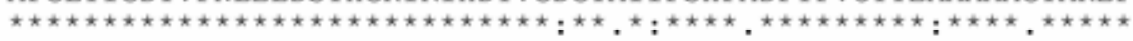

AF 327046

X96551

P52573

AY336994

ZmPER1

BT016686

AF 327046

X96551

P52573

AY336994

ZMPER1

BT016686

AF 327046

X96551

P52573

AY336994

ZMPER1

BT016686

\begin{abstract}
EKRGVKLLGISCDDVQSHKEWTKDIEAYKPGS--------KVTYPIMADPDRSAIKQLNM 112 EKRGVKLLGISCDDVQSHKEWTKDIEAYKPGS-------KVTYPIMADPDRSAIKQLNM 112 DKRGVKLLGISCDDVQSHKDWFKDIEAYKPGN--------RVTYPIMADPSREAIKQLNM 112 DKRGVKLLGISCDDVQSHKDWIKDIEAYKPGN--------RVTYPIMADPSREAIKQLNM 112 EKRGVKLLGISCDDVESHRQWTKDVEAYGGKQQQQQATTTKVTFPILADPARDAIRQLNM 120 EKRGVKLLGISCDDVESHRQWTKDVEAYGGKQ---QTTTTKVTFPILADPARDAIRQLNM 117

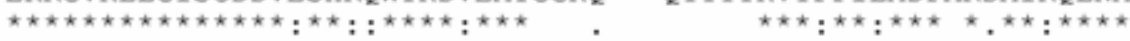

VDPDEKDAEG-QLPSRTLHIVGPDKKVKLSFLYPSCTGRNMDEVVRAVDSLLTAAKH--K 169 VDPDEKDAQG-QLPSRTLHIVGPDKVVKLSFLYPSCTGRNMDEVVRAVDSLLTAAKH--K 169 VDPDEKDSNGGHLPSRALHIVGPDKKVKLSFLYPACVGRNMDEVVRAVDALQTAAKT--R 170 VDPDEKDSNGGHLPSRALHIVGPDKKVKLSFLYPACVGRNMDEVVRAVDALQTAAKHA-- 170 VDPDEKDAAGRSMPSRALHVVGPDKAVKLSFLYPATTGRNMDEVLRAVDSLLTAAKHGGK 180 VDPDEKDAAGRSMPSRALHVVGPDKAVKLSFLYPATTGRNMDEVLRAVDSLLTAAKHGGK 177

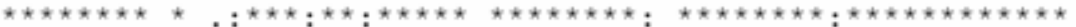

Fig. 7. Sequence homology comparisons between PER1 from maize and other plants. PER1-HV, a peroxiredoxin antioxidant protein encoded by a dormancyrelated gene from barley (Hordeum vulgare, X96551) (47); PER1-TT, a 1-cys peroxiredoxin protein from wheat (Triticum turgidum subsp. durum, AF327046) that is induced under salt stress; PER1-OS, a rice (japonica cultivar group) peroxiredoxin gene (AF336994); P52573, a RAB24 protein from rice; PER1-ZM, the deduced amino acid sequences of the cloned maize per1 cDNA (accession no. DQ378060, this study); and BT016686, the deduced amino acid sequences of a maize clone contig519 mRNA. The underlines indicate the peptide sequences of spot 537 obtained from electrospray ionization tandem mass spectrometry. The conserved amino acid residues are indicated with “*” and the putative conserved active site sequence is highlighted. 


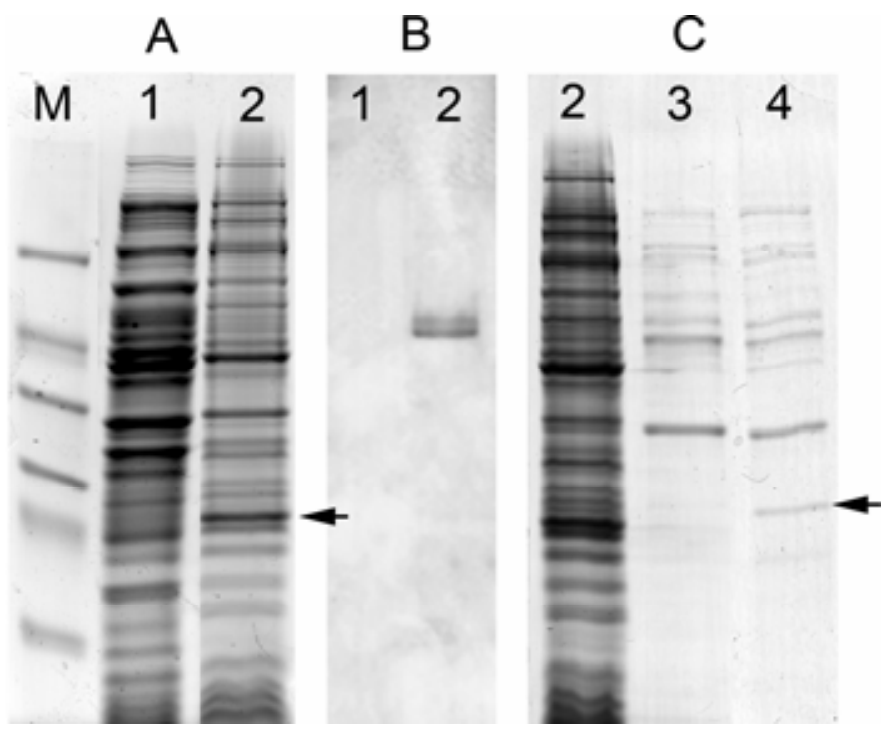

Fig. 8. Overexpression of maize PER1 and demonstration of peroxidase activity in vitro. A, Sodium dodecyl sulfate polyacrylamide gel electrophoresis (SDS-PAGE) showing overexpressed PER1 protein (arrow) in induced total Escherichia coli cell extract (lane 2) compared with the control (lane 1). $\mathrm{M}=$ protein markers (from top, albumin, $66 \mathrm{kDa}$; ovalbumin, $45 \mathrm{kDa}$; glyceraldehyde-3-phosphate dehydrogenase, $36 \mathrm{kDa}$; carbonic anhydrase, $29 \mathrm{kDa}$; trypsinogen, $24 \mathrm{kDa}$; and trypsin inhibitor, $20 \mathrm{kDa}$ ). B, The same two samples were resolved in a native PAGE gel and stained for peroxidase activity. $\mathbf{C}$, The gel areas corresponding to the activity band in lanes 1 and 2 were recovered from B, eluted, and reloaded on another SDS-PAGE on lanes 3 and 4, respectively, confirming the observed activity was from the overexpressed maize PER1 protein.

species in host plants during a pathogen attack or stress has been documented (59). However, the possibility of PER1 involved in a secondary stress-related response cannot be ruled out. It has been demonstrated that biotic stresses could induce the expression of genes involved in abiotic stress responses and, vice versa, through some common regulatory factors $(7,14,20,26,36)$. High-level expression of PER1, other stress-related proteins, storage proteins, and antifungal proteins identified in proteomic comparisons may act in concert either directly through inhibiting fungal infection or indirectly through enhancing host stress tolerance to reduce aflatoxin contamination in resistant maize genotypes. However, uncovering the exact role of PER1 in host resistance will require further investigation. RNA silencing of PER1 expression may provide direct evidence of this protein's importance to maize aflatoxin-resistance.

\section{ACKNOWLEDGMENTS}

This study was supported by United States Department of Agriculture (USDA) cooperative agreement 58-6435-6-055, USDA Agricultural Research Service Aflatoxin Elimination Workshop, and USDA National Research Initiative Competitive Grant 2002-35201-12541. Published with the approval of the Director of the Louisiana Agricultural Experiment Station as manuscript number 07-38-0004. We thank C. Ambrogio, Q. Wei, N. Hazard, and A. Angeles for technical assistance; and S. Boue, K. Rajasekaran, and G. Windham for critical reviewing of the manuscript.

\section{LITERATURE CITED}

1. Altschul, S. F., Madden, T. L., Schäffer, A. A., Zhang, J.-H., Zhang, Z., Miller, W., and Lipman, D. J. 1997. Gapped BLAST and PSI-BLAST: A new generation of protein database search programs. Nucleic Acids Res. 25:3389-3402.

2. Bradford, M. M. 1976. A rapid and sensitive method for the quantitation of microgram quantities of protein utilizing the principle of protein-dye binding. Anal. Biochem. 72:248-254.

3. Brown, R. L., Chen, Z.-Y., Cleveland, T. E., and Russin, J. S. 1999. Advances in the development of host resistance to aflatoxin contami-
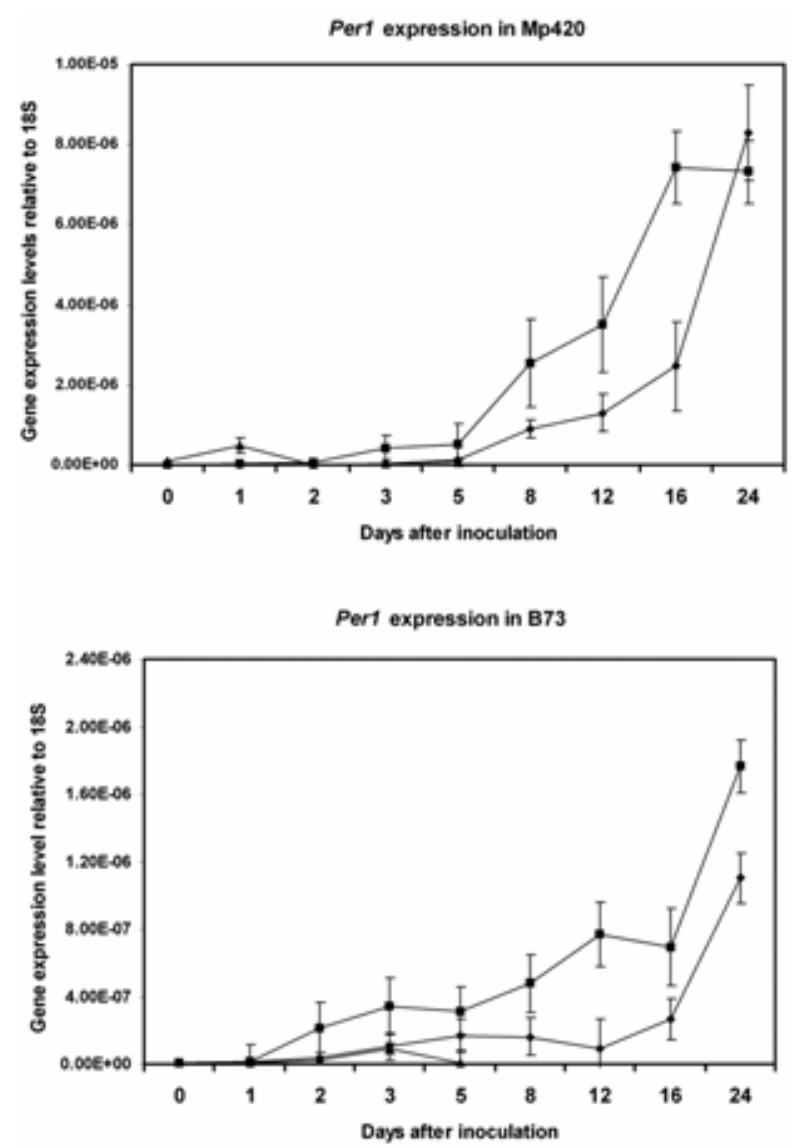

Fig. 9. Expression of peroxiredoxin antioxidant gene during kernel developmental stages with or without Aspergillus flavus inoculation in maize. Maize ears were inoculated 7 days after pollination. Transcript levels (mean with standard error bars) of the per 1 gene were measured at $0,1,2,3,5,8,12,16$, and 24 days after inoculation using real-time reverse-transcription polymerase chain reaction and are expressed as relative to $18 \mathrm{~S}$ (internal normalizer) in the resistant (Mp420) and susceptible (B73) maize genotypes; $\bullet$, perl expression in nonwounded control kernels; $\mathbf{\square}$, perl expression in wound inoculated kernels; and $\boldsymbol{\Delta}$, perl expression in wounded only control kernels.

nation by Aspergillus flavus. Phytopathology 89:113-117.

4. Brown, R. L., Cleveland, T. E., Payne, G. A., Woloshuk, C. P., Campbell, K. W., and White, D. G. 1995. Determination of resistance to aflatoxin production in maize kernels and detection of fungal colonization using an Aspergillus flavus transformant expressing Escherichia coli $\beta$-glucuronidase. Phytopathology 85:983-989.

5. Campbell, K. W., and White, D. G. 1995. Evaluation of corn genotypes for resistance to Aspergillus ear rot, kernel infection, and aflatoxin production. Plant Dis. 79:1039-1045.

6. Chae, H. Z., Chung, S. J., and Rhee, S. G. 1994. Thioredoxindependent peroxide reductase from yeast. J. Biol. Chem. 269:27670-27678.

7. Chen, Z.-Y., Brown, R. L., and Cleveland, T. E. 2004. Evidences of an association between stress tolerance and host resistance in corn against Aspergillus flavus infection and aflatoxin contamination. Afr. J. Biotechnol. 3:693-699.

8. Chen, Z.-Y., Brown, R. L., Cleveland, T. E., Damann, K. E., and Russin, J. S. 2001. Comparison of constitutive and inducible maize kernel proteins of genotypes resistant or susceptible to aflatoxin production. J. Food Prot. 64:1785-1792.

9. Chen, Z.-Y., Brown, R. L., Damann, K. E., and Cleveland, T. E. 2002. Identification of unique or elevated levels of kernel proteins in aflatoxinresistant maize genotypes through proteome analysis. Phytopathology 92:1084-1094

10. Chen, Z.-Y., Brown, R. L., Damann, K. E., and Cleveland, T. E. 2004. Identification of a maize kernel stress-related protein and its effect on aflatoxin accumulation. Phytopathology 94:938-945.

11. Chen, Z.-Y., Brown, R. L., Lax, A. R., Cleveland, T. E., and Russin, J. S. 1999. Inhibition of plant pathogenic fungi by a corn trypsin inhibitor over-expressed in Escherichia coli. App. Environ. Microbiol. 65:13201324.

12. Chen, Z.-Y., Brown, R. L., Lax, A. R., Guo, B. Z., Cleveland, T. E., and 
Russin, J. S. 1998. Resistance to Aspergillus flavus in corn kernels is associated with a 14-kDa protein. Phytopathology 88:276-281.

13. Chen, Z.-Y., Brown, R. L., Rajasekaran, K., Damann, K. E., and Cleveland, T. E. 2006. Evidence for involvement of a pathogenesis-related protein in maize resistance to Aspergillus flavus infection /aflatoxin production. Phytopathology 96:87-95.

14. Cheong, Y. H., Chang, H. S., Gupta, R., Wang, X., Zhu, T., and Luan, S. 2002. Transcriptional profiling reveals novel interactions between wounding, pathogen, abiotic stress, and hormonal responses in Arabidopsis. Plant Physiol. 129:661-677.

15. Cordero, M. J., Raventós, D., and San Segundo, B. 1992. Induction of PR proteins in germinating maize seeds infected with the fungus Fusarium moniliforme. Physiol. Mol. Plant Pathol. 41:189-200.

16. Dal Bosco, C., Busconi, M., Govoni, C., Baldi, P., Stanca, A. M., Crosatti, C., Bassi, R., and Cattivelli, L. 2003. cor Gene expression in barley mutants affected in chloroplast development and photosynthetic electron transport. Plant Physiol. 131:793-802.

17. Davis, G. L., and Williams, W. P. 1999. QTL for aflatoxin reduction in maize. Maize Genet. Conf. 41:22.

18. Dietz, K. J. 2003. Plant peroxiredoxins. Annu. Rev. Plant Biol. 54:93-107.

19. Dietz, K. J., Jacob, S., Oelze, M. L., Laxa, M., Tognetti, V., de Miranda, S. M. N., Baier, M., and Finkemeier, I. 2006. The function of peroxiredoxins in plant organelle redox metabolism. J. Exp. Bot. 57:1697-1709.

20. Evers, D., Ghislain, M., Hausman, J. F., and Dommes, J. 2003. Differential gene expression in two potato lines differing in their resistance to Phytophthora infestans. J. Plant Physiol. 160:709-712.

21. Galau, G. A., Wang, H. Y., and Hughes, D. W. 1993. Cotton Lea5 and Lea14 encode atypical late embryogenesis-abundant proteins. Plant Physiol. 101:695-696.

22. Gardner, C. A. C., Darrah, L. L., Zuber, M. S., and Wallin, J. R. 1987. Genetic control of aflatoxin production in maize. Plant Dis. 71:426-429.

23. Görg, A., Boguth, G., Obermaier, C., and Weiss, W. 1998. Two-dimensional electrophoresis of proteins in a immobilized $\mathrm{pH}$ 4-12 gradient. Electrophoresis 19:1516-1519.

24. Guo, B. Z., Chen, Z.-Y., Brown, R. L., Lax, A. R., Cleveland, T. E., Russin, J. S., Mehta, A. D., Selitrennikoff, C. P., and Widstrom, N. W. 1997. Germination induces accumulation of specific proteins and antifungal activities in corn kernels. Phytopathology 87:1174-1178.

25. Guo, B. Z., Russin, J. S., Cleveland, T. E., Brown, R. L., and Widstrom, N. W. 1996. Resistance to aflatoxin contamination in corn as influenced by relative humidity and kernel germination. J. Food Prot. 59:276-281.

26. Gutterson, N., and Reuber, T. L. 2004. Regulation of disease resistance pathways by AP2/ERF transcription factors. Curr. Opin. Plant Biol. 7:465-471.

27. Haslekas, C., Stacy, R. A., Nygaard, V., Culianez-Macia, F. A., and Aalen, R. B. 1998. The expression of a peroxiredoxin antioxidant gene, AtPerl, in Arabidopsis thaliana is seed-specific and related to dormancy. Plant Mol. Biol. 36:833-845

28. Hsieh, D. P. H. 1989. Potential human health hazards of mycotoxins. Pages 69-80 in: Mycotoxins and Phycotoxins. S. Natori, K. Hashimoto, and Y. Ueno, eds. Elsevier, Amsterdam.

29. Huang, Z., White, D. G., and Payne, G. A. 1997. Corn seed proteins inhibitory to Aspergillus flavus and aflatoxin biosynthesis. Phytopathology 87:622-627.

30. Jones, R. K., Duncan, H. E., and Hamilton, P. B. 1981. Planting date, harvest date, and irrigation effects on infection and aflatoxin production by Aspergillus flavus in field corn. Phytopathology 71:810-816.

31. Kiba, A., Nishihara, M., Tsukatani, N., Nakatsuka, T., Kato, Y., and Yamamura, S. 2005. A peroxiredoxin Q homolog from Gentians is involved in both resistance against fungal disease and oxidative stress. Plant Cell Physiol. 46:1007-1015.

32. King, S. B., and Scott, G. E. 1982. Field inoculation techniques to evaluate for reaction to kernel infection by Aspergillus flavus. Phytopathology 72:782-785.

33. Laemmli, U. K. 1970. Cleavage of structural proteins during the assembly of the head of bacteriophage T4. Nature 227:680-685.

34. Lee, K. O., Jang, H. H., Jung, B. G., Chi, Y. H., Lee, J. Y., Choi, Y. O., Lee, J. R., Lim, C. O., Cho, M. J., and Lee, S. Y. 2000. Rice 1-cys peroxiredoxin over-expressed in transgenic tobacco does not maintain dormancy but enhances antioxidant activity. FEBS Lett. 486:103-106.

35. Marchler-Bauer, A., and Bryant, S. H. 2004. CD-Search: Protein domain annotations on the fly. Nucleic Acids Res. 32:W327-331.

36. Mengiste, T., Chen, X., Salmeron, J., and Dietrich, R. 2003. The BOTRYTIS SUSCEPTIBLE1 gene encodes an R2R3MYB transcription factor protein that is required for biotic and abiotic stress responses in Arabidopsis. Plant Cell 15:2551-2565.
37. Mowla, S. B., Thomson, J. A., Farrant, J. M., and Mundree, S. G. 2002. A novel stress inducible antioxidant enzyme identified from the resurrection plant Xerophyta viscosa Baker. Planta 215:716-726.

38. Nichols, T. E., Jr. 1983. Economic impact of aflatoxin in corn. South. Coop. Ser. Bull. 279:67-71.

39. Paul, C., Naidoo, G., Forbes, A., Mikkilineni, V., White, D., and Rocheford, T. 2003. Quantitative trait loci for low aflatoxin production in two related maize populations. Theor. Appl. Genet. 107:263-270.

40. Payne, G. A. 1998. Process of contamination by aflatoxin-producing fungi and their impact on crops. Pages 279-306 in: Mycotoxins in Agriculture and Food Safety. K. K. Sinha and D. Bhatnagar, eds. Marcel Dekker, New York.

41. Payne, G. A., Cassel, D. K., and Adkins, C. R. 1986. Reduction of aflatoxin contamination in corn due to irrigation and tillage. Phytopathology 76:679-684.

42. Rouhier, N., Gelhaye, E., Gualberto, J. M., Jordy, M.-N., De Fay, E., Hirosawa, M., Duplessis, S., Lemaire, S. D., Frey, P., Martin, F., Manieri, W., Knaff, D. B. and Jacquot, J.-P. 2004. Poplar peroxiredoxin Q. A thioredoxin-linked chloroplast antioxidant functional in pathogen defense. Plant Physiol. 134:1027-1038.

43. Scott, G. E., and Zummo, N. 1988. Sources of resistance in maize to kernel infection by Aspergillus flavus in the field. Crop Sci. 28:504-507.

44. Shimoni, M., Reuveni, R., and Bar-Zur, A. 1996. Relation between peroxidase, beta-1,3-glucanase, the se gene and partial resistance of maize to Exserohilum turcicum. Can. J. Plant Pathol. 18:403-408.

45. Smith, J. E., and Moss, M. O. 1985. Mycotoxins: Formation Analyses and Significance. John Wiley and Sons, Chichesster, NY.

46. Squire, R. A. 1981. Ranking animal carcinogens: A proposed regulatory approach. Science 214:877-880.

47. Stacy, R. A., Munthe, E., Steinum, T., Sharma, B., and Aalen, R. B. 1996. A peroxiredoxin antioxidant is encoded by a dormancy-related gene, Perl, expressed during late development in the aleurone and embryo of barley grains. Plant Mol. Biol. 31:1205-1216.

48. Stacy, R. A. P., Nordeng, T. W., Culianez-Macia, F. A., and Aalen, R. B. 1999. The dormancy-related peroxiredoxin anti-oxidant, PER1, is localized to the nucleus of barley embryo and aleurone cells. Plant J. 19:1-8.

49. Subramanian, B., Bansal, V. K. and Kav, N. N. 2005. Proteome-level investigation of Brassica carinata-derived resistance to Leptosphaeria maculans. J. Agric. Food Chem. 53:313-324.

50. Sun, J. L., Nakagawa, H., Karita, S., Ohmiya, K., and Hattori, T. 1996. Rice embryo globulins: Amino-terminal amino acid sequences, cDNA cloning and expression. Plant Cell Physiol. 37:612-620.

51. Tertivanidis, K., Goudoula, C., Vasilikiotis, C., Hassiotou, E., Perl-Treves, R., and Tsaftaris, A. 2004. Superoxide dismutase transgenes in sugarbeets confer resistance to oxidative agents and the fungus Cercospora beticola. Transgenic Res. 13:225-233.

52. Thomann, E. B., Sollinger, J., White, C., and Rivin, C. J. 1992. Accumulation of group 3 late embryogenesis abundant proteins in Zea mays embryos. Plant Physiol. 99:607-614.

53. Tseng, T. S., Yeh, K. W., Yeh, C. H., Chang, F. C., Chen, Y. M., and Lin, C. Y. 1992. Two rice (Oryza sativa) full-length cDNA clones encoding low-molecular-weight heat-shock proteins. Plant Mol. Biol. 18:963-965.

54. Veena, Reddy, V. S., and Sopory, S. K. 1999. Glyoxalase I from Brassica juncea: Molecular cloning, regulation and its over-expression confer tolerance in transgenic tobacco under stress. Plant J. 17:385-395.

55. Wallace, N. H., and Kriz, A. L. 1991. Nucleotide sequence of a cDNA clone corresponding to the maize globulin-2 gene. Plant Physiol. 95:973-975.

56. White, C. N., and Rivin, C. J. 1995. Sequence and regulation of a late embryogenesis abundant group 3 protein of maize. Plant Physiol. 108:1337-1338.

57. Widstrom, N. W., McMillian, W. W., and Wilson, D. M. 1987. Segregation for resistance to aflatoxin contamination among seeds on an ear of hybrid maize. Crop Sci. 27:961-963.

58. Williams, W. P., Windham, G. L., Buckley, P. M., and Perkins, J. M. 2005. Southwestern corn borer damage and aflatoxin accumulation in conventional and transgenic corn hybrids. Field Crop Res. 91:329-336.

59. Wojtaszek, P. 1997. Oxidative burst: An early plant response to pathogen infection (review). Biochem. J. 322:681-692.

60. Woloshuk, C. P., Cavaletto, J. R., and Cleveland, T. E. 1997. Inducers of aflatoxin biosynthesis from colonized maize kernels are generated by an amylase activity from Aspergillus flavus. Phytopathology 87:164-169.

61. Xu, D., Duan, X., Wang, B., Hong, B., Ho, T. H. D., and Wu, R. 1996. Expression of a late embryogenesis abundant protein gene, HVA1, from barley confers tolerance to water deficit and salt stress in transgenic rice. Plant Physiol. 110:249-257. 